\title{
Model of Vocational School, High School and Manufacture Integration in the Regional System of Professional Education
}

\author{
Albina R. Shaidullina ${ }^{1}$, Dmitry A. Krylov ${ }^{2}$, Viktoriya V. Sadovaya ${ }^{3}$, Gulnaz R. Yunusova ${ }^{3}$, Stanislav O. Glebov ${ }^{3}$, \\ Alfiya R. Masalimova $^{2} \&$ Irina V. Korshunova ${ }^{3}$ \\ ${ }^{1}$ Almetyevsk State Oil Institute, Almetyevsk, Russia \\ ${ }^{2}$ Mari State University, Yoshkar-Ola, Russia \\ ${ }^{3}$ Kazan Federal University, Kazan, Russia
}

Correspondence: Albina R. Shaidullina, Foreign Languages' Department, Almetyevsk State Oil Institute, Almetyevsk, 423450, Russia. E-mail: albina-plus@mail.ru

\author{
Received: October 24, 2014 Accepted: December 3, 2014 Online Published: December 18, 2014 \\ doi:10.5539/res.v7n1p63 URL: http://dx.doi.org/10.5539/res.v7n1p63
}

\begin{abstract}
Integration of vocational, high schools and manufacture contributes to qualified personnel for the regional oil industry effective training. So this article is aimed at the model development of vocational, high school and manufacture integration in the regional system of vocational education. The basic approach to the structural-functional model development of vocational, high school and manufacture integration in the regional system of vocational education is an integrative one, taking into consideration the integrated system "vocational school-high school-manufacture" components in their unity and cooperation, giving it the integrity and structural and functional stability. Structural-functional model of vocational, high school and manufacture integration in the regional system of vocational education includes functional-target, organizational-structural, content, process and result components.
\end{abstract}

Keywords: integration, vocational school, high school, manufacture, structural-functional model, industry

\section{Introduction}

Vocational, high school and manufacture integration contributes to qualified personnel effective training for the region oil industry in conditions of unite integrated educational-industrial complex "vocational school — high school-manufacture", in which integrated system's all participants joint and coordinated efforts should be aimed at a synergy effect obtaining from these joint actions (Shaidullina, 2012). The developed "Strategy of chemical and petrochemical industry development of Russia for the period till 2015" takes into account the increase in domestic consumption of primary resources and the export products with high added value, which require new refining enterprises construction (The development strategy of the chemical and petrochemical industry in Russia till 2015). In this regard, the government is pinning great hopes on the complex of measures making for the chemical and petrochemical industry development, which, like other sectors of the economy are undergoing transition to a new technological level on the basis of innovative partnership of the state, business, and Russian science and education forming.

However, this industrial-technological level can be achieved only on the basis of new technologies and innovations, the development of which require from modern technical specialists not only their professional skills to build their activities on the conceptual and technological (mechanisms, methods and means) levels, but also their activities reflection on methodological level (principles, approaches), their activities embedding in a conceptual context, professional activities' effects foreseeing.

Such many-sided training of technical specialists requires as multi interpenetration of educational, research and manufacture processes, so educational institutions of professional education, educational programs content, training and education technologies, organizational and management forms, financial and economic resources and manufacture processes integration (Mukhametzyanova \& Shaydullina, 2011). The analysis of regional concepts of integration in pedagogical science, allows making a conclusion that most of them reveal integration on the level of organizational-management cooperation. However, it is necessary to take into consideration the integration of vocational schools, high schools and manufacture in the regional system of professional education 
as on organizational-structural, so on substantial and technological levels (Shaidullina \& Fatkhullina, 2013; Zhurakovsky \& Sazonova, 2010).

\section{Materials and Methods}

At the structural-functional model of vocational school, high school and manufacture integration developing in the regional system of vocational education the following methods were used:

- theoretical: comparative analysis of psychological and pedagogical literature on the research problem; concretization and generalization, universalization and unification, transformation and conversion, idealization and extrapolation; analysis program and normative documents of the Education and Science Ministry of Russian Federation and Republic of Tatarstan, revealing the main aspects of the problem; benchmarking, modeling, design; the method of mental experiment and others;

- empirical: the experiences study of vocational schools, high schools and industry; psychological and pedagogical methods of information collection (pedagogical supervision, the method of expert estimates, interviews, surveys, study of the experience of teaching, the analysis of results of activity of students, the analysis of examination results, including graduation, course and diploma works, diagnostic techniques); ascertaining and forming experiments;

- statistics: statistical analysis and meaningful interpretation of the study results, their mathematical processing, grouping, and others.

The experimental base of the research was Almetyevsk state oil institute, Almetyevsk polytechnic college, JSC "Tatneft".

\section{Results}

Structural-functional model of vocational, high schools and manufacture integration in the regional system of vocational education demonstrates the participants' functions correlation in the integrated system "vocational school-high school-manufacture", their inclusion in all processes of educational activities related to a specialist professional forming. Integrative approach creates conditions for elements constant interaction as within the system, so with the external environment. The main sign of integration productivity is not the links quantity, but integrative wholeness of its component parts. The necessary condition for the integrated system "vocational school — high school—manufacture" development are functionally stable connections of professional education schools and industrial manufacture structures.

Functionally-target block of the model is a set of goals (structural and functional stability, which provides the integrated system development its participants competitiveness improvement) and tasks (a unite direction on the overall development and self-development of an integrated system; the cluster policy development in the Republic of Tatarstan; social partnership development; the integrated system participants cohesion ensuring; technical education content upgrading, providing advanced training; the integrated system participants potential realization aimed at its development and reorganization).

Integrative approach, which is used at the structural-functional model development of vocational schools, high schools and manufacture integration in the regional system of vocational education, creates conditions for the elements continuous interaction as within the system, so also with the external environment (Shaidullina \& Ziyatdinov, 2013).

As the basic principles for the vocational schools, high schools and manufacture integration in the model the following ones are indicated: synergetic principle, implying coordinated communications number increasing to promote qualitatively new features of the integrated system emergence; relevance principle, allowing integrated forms of cooperation forming and development via previously disparate parts and elements reunification into the whole; symbiosis principle, aimed at linkages strengthening between elements of the integrated system "vocational school - high school—manufacture" with the system integrity forming purpose; clustering principle, that means professional education schools of different levels integration according their industry sector direction (Golyshev, 2011); systematic principle, which means organically mutual penetration and complementarity of integrated systems external and internal elements (Ursul, 2008).

Structural and functional stability of these participants integration in the regional system of vocational education is achieved via unite integrated educational-industrial complex creation, which is determined by the following functions: coordinating function, aimed at the coordinated cooperation of the social infrastructure, customers and employers in the region, taking into account specific interests of educational process participants, as well as the transition from traditional hard-regulated forms of management on the level of self-management and 
self-government; corporate function, involving joint efforts and actions of the integrated system "vocational school-high school-manufacture" participants, aimed at interests consolidation in order to preserve its integrity as an independent amalgamation; anticipatory function, involving the implementation of education and manufactory tasks joint solution that contribute to anticipatory advanced practice with innovative equipment using to obtain a qualitatively new knowledge and forecast scientific-technical development of the world; sublimating function, meaning one participants mechanisms using to achieve goals of another participants in the integrated system, because independent task solution was impossible previously for them (Masalimova \& Shaidullina, 2006); reorganizational function aimed at content updating and upgrading of education in an integrated system "vocational school — high school—manufacture" taking into account the requirements of the social order and the market economy.

Organizational-structural unit includes: requirements consistency to the students training quality in Almetyevsk polytechnic vocational school (APVS) and the Almetyevsk state oil institute (ASOI) with JSC "Tatneft"; consistency of legislative and regulatory frameworks in APVS, ASOI and JSC "Tatneft".

Content unit means: coherence of educational curricula of the APVS and ASOI in related disciplines; the content consistency of academic disciplines in APVS and ASOI; consistency of training and methodological support content in APVS and ASOI; practical training consistency in APVS and ASOI with the enterprises of JSC "Tatneft".

Technological unit: training forms and methods consistency in APVS and ASOI, common types of educational activity and types of knowledge control (Fig. 1).

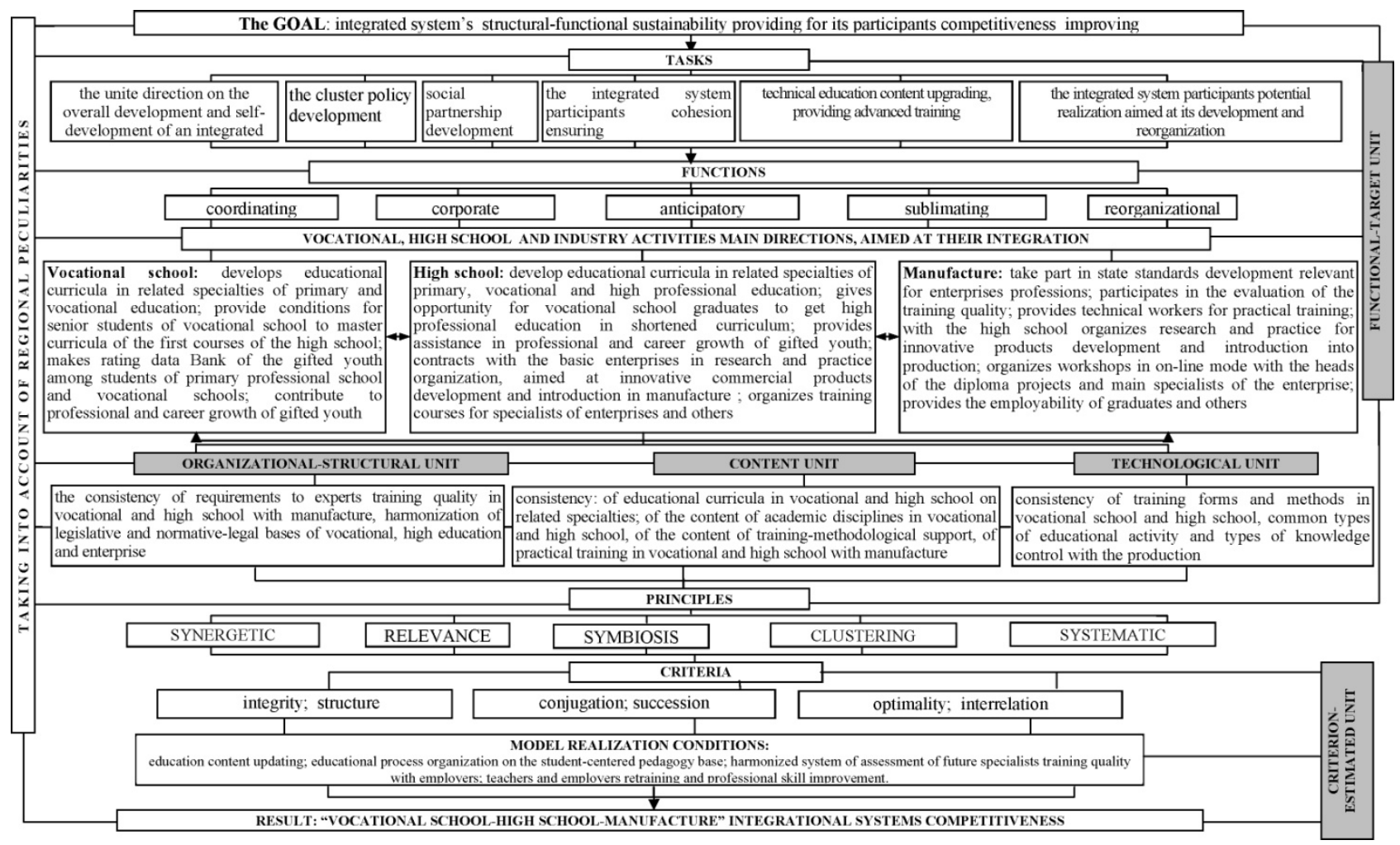

Figure 1. Structural-functional model of vocational, high schools and manufacture integration

In criterion-estimated unit the selection criteria of the integration process are distinguished: integrity (the presence of industry sector educational cluster; the stability of integrated system relationships (the number of long-term partnership agreements); structure (list of integrated structures, cooperation collective management bodies; multidirectional activity of the integrated system participants); conjugation (availability of technologies for content concordance in curricula educational disciplines of vocational school education and high school education on related specialties); the content coherence of training and methodological support in the schools of vocational and high school; succession (continuity of training and methodological support of the integrated 
system; interdisciplinary curricula; availability of educational curricula on "breakthrough" and interdisciplinary directions); optimality (the degree of educational material mastering; the possibility of joint use of equipment and teachers inviting); interrelation (adequacy of the coordinated forms and methods of teaching in vocational school, high school and manufacture; the continuity of activities and control); adaptability (graduates number, finding the job; the share of vocational school graduates, the share of those, who continue education at the high school; duration of staying at the work place); competitiveness (the relevance of educational institutions on the market of educational services, the demand for graduates in enterprises; the degree of students satisfaction by the educational space of vocational or high school).

According to the criteria the prevalence of this or that type of APVS, ASOI and JSC "Tatneft" integration was assessed. Significantly as a general integral index of the integration process of APVS, ASOI and JSC "Tatneft" increased so indicators for selected criteria. The greatest changes occurred in the indicators: number of graduates, who found jobs; the stability of relationships in integrated structure; the possibility of joint use of equipment and teachers inviting; duration of staying at the work place.

The proposed structural-functional model of vocational schools, high schools and manufacture integration in the regional system of vocational education, which includes functional-target, organizational-structural, content, process and result components, allows to predict the integrated system "vocational school-high school - manufacture" transition on a qualitatively new level due to the agreed goals, objectives, functions and activities of the system participants and its structure reorganization in conditions of the integrated educational-industrial complex.

\section{Discussions}

In previous studies various problems of integration in education are taken into consideration, in particular: issues of continuing professional education (Vladislavlev, 1989; Mukhametzyanova, 2005; Novikov, 2005, etc.); the integration of school, high school and industry (Chudov, 2004; Shaidullina, 2009 etc.); integration of education, science and manufacture (Mukhametzyanova, 2005; Sazonova, Sidyakina \& Ishchenko, 2010, etc.); integration of education and industry (Smirnov, 2001; Tkachenko, 2004 etc.); the inter-subject integration of pedagogical knowledge (Bezrukova, 1994; Zagvyazinsky, 1990, etc.); the integrated management of the secondary and professional education (Berulava, 1990; Ibragimov, 2011; Fedotova, 1995), and other

However, analysis of scientific and pedagogical literature on the research topic and relevant experience of practical activity, allow conclude that the model for vocational school, high school and manufacture integration in the region conditions wasn't developed yet in them.

\section{Conclusion}

Thus, the structural-functional model of vocational school, high school and manufacture integration in the regional system of vocational education, which includes functional-target, organizational-structural, content, process and result components, allows to predict the integrated system "vocational school-high school-manufacture" transition on a qualitatively new level due to the agreed goals, objectives, functions and activities of this system participants, contributing to technical specialists advanced training realization.

\section{Recommendations}

The materials of this article can be useful for teachers in technical specialists training content designing in vocational schools and high schools; as well as for the administration of the institutions of vocational and higher professional education at integration strategy determining with manufacture.

Taking into account the results of the conducted research it is possible to identify a number of scientific problems and promising areas requiring further study: study of issues related to management of education and industry integration at the strategic, tactical and operational levels; solving problems on the development of technical specialists competency model for realization of innovation projects in the oil industry.

\section{References}

Berulava, M. N. (1990). Integration of general and vocational education. Sovietpedagogy, 9, 57-60.

Bezrukova, V. S. (1994). Integration processes in teaching theory and practice (p. 152). Ekaterinburg.

Chudov, V. L. (2004). System integration of the Lyceum, the university and production for sustainable development of quality educational training (p. 192). Software Radio Press.

Fedotova, L. D. (1995). Didactic principles of forming an integrated content of initial vocational training (p. 112). Moscow. 
Golyshev, I. G. (2011). Management of integration processes in the field of vocational education as a system of black box. Siberian pedagogical journal, 7, 254-261.

Ibragimov, G. I. (2011). Innovative learning technologies in the conditions of implementation of competence-based approach. Innovations in Education, 4, 4-15.

Masalimova, A. R., \& Shaidullina, A. R. (2006). Foreign experience of integration of research, teaching and practice of students of higher technical school. Kazan Pedagogical Journal, 5(47), 54-61.

Mukhametzyanova, G. V. (2005). Professional education: Problems of quality and academic support (p. 319). Magarif Press.

Mukhametzyanova, G. V., \& Shaidullina, A. R. (2011). Regional Integration Processes in the Vocational Education System (1st ed., p. 232). Idel Press.

Novikov, A. M. (2005). Development of national education: Polemical reflections (p. 176). Egves Press.

Sazonova, Z. S., Sidyakina, N. Y., \& Ishchenko, V. V. (2010). Training managers of high technology: Student-approach. Higher Education in Russia, 4, 27-35.

Shaidullina, A. R. (2009). Principles of integration ssuz-university-production in terms of continuing professional education. Higher Education in Russia, 5, 140-144.

Shaidullina, A. R. (2012). Regional Experience of Integration in System Vocational School-High School-Manufacture. Memoirs of Almetyevsk State Oil Institute, 2, 306-312.

Shaidullina, A. R., \& Ziyatdinov, A. M. (2013). Electronic Science and Technology Journal as a mechanism for the integration of science, education and industry. Herald of Kazan Technological University, 16, 78-81.

Shaidullina, A. R., \& Fatkhullina, R. A. (2013). Education system of innovative entrepreneurship in continuing professional education. Theory and practice of modern vocational education, 1, 134-138.

Smirnov, I. P., \& Tkachenko, E. V. (2004). Social partnership: What awaits employers? (Results of the pilot the All-Russian social studies) (p. 32). Aspect Press.

Tkachenko, E. V. (2001). Basics regionalization basic vocational education (p. 42). Centre APO Press.

Ursul, A. (2008). Principle of temporal integrity and education. Herald of high school, 3, 28-35.

Vladislavlev, A. P. (1989). In search of the concept. Bulletin of high school, 6, 48-51.

Zagvyazinsky, V. I. (1990). Indirect impact on the methodology of practice. Sovietpedagogy, 3, 65-67.

Zhurakovsky, V. M., \& Sazonova, Z. S. (2010). Actual problems of modernization of vocational education. Higher education in Russia, 5, 4-12.

\section{Copyrights}

Copyright for this article is retained by the author(s), with first publication rights granted to the journal. This is an open-access article distributed under the terms and conditions of the Creative Commons Attribution license (http://creativecommons.org/licenses/by/3.0/). 